E3S Web of Conferences 1, 33001 (2013)

DOI: $10.1051 / \mathrm{e} 3$ sconf/20130133001

(C) Owned by the authors, published by EDP Sciences, 2013

\title{
Lead isotope ratios as a tracer for lead contamination sources: A lake Andong case study
}

\author{
Y. H, Kim, K. J. Kim, E. H. Kim, J. J. Park, S. M. Kim and K. S. Seok
}

Chemicals Research Division, National Institute of Environmental Research, Incheon, 404-708, Republic of Korea, heek89@korea.kr

\begin{abstract}
The objective of this study was to evaluate stable $\mathrm{Pb}$ isotope signatures as a tracer for $\mathrm{Pb}$ contamination in Lake Andong. For Pb isotope analysis, we collected water and sediment from Lake Andong, particles in the air, soils, and stream water, mine tailings, sludge and wastewater from zinc smelting around lake Andong watershed. The results showed that $\mathrm{Pb}$ isotope ratios $\left({ }^{206} \mathrm{~Pb} /{ }^{204} \mathrm{~Pb},{ }^{207} \mathrm{~Pb} /{ }^{204} \mathrm{~Pb}\right.$, and $\left.{ }^{208} \mathrm{~Pb} /{ }^{204} \mathrm{~Pb}\right)$ for zinc concentrate were $18.809 \pm 0.322,15.650 \pm 0.062$, and $38.728 \pm 0.421$, respectively. In wastewater, isotopic ratio values $\left({ }^{206} \mathrm{~Pb} /{ }^{204} \mathrm{~Pb},{ }^{207} \mathrm{~Pb} /{ }^{204} \mathrm{~Pb}\right.$, and $\left.{ }^{208} \mathrm{~Pb} /{ }^{204} \mathrm{~Pb}\right)$ were $17.363 \pm 0.133,15.550 \pm 0.025$, and $37.217 \pm 0.092$, respectively. Additionally, isotopic ratio values $\left({ }^{206} \mathrm{~Pb} /{ }^{204} \mathrm{~Pb},{ }^{207} \mathrm{~Pb} /{ }^{204} \mathrm{~Pb}\right.$, and $\left.{ }^{208} \mathrm{~Pb} /{ }^{204} \mathrm{~Pb}\right)$ for sludge were $17.515 \pm 0.155,15.537 \pm 0.018$, and $37.357 \pm 0.173$, respectively. These values were similar to those in zinc and lead concentrate originated from Canada and South America. In contrast, Pb isotope ratios of soil, tailings and sediment from Lake Andong were similar to those of Korean ore. Atmospheric particles showed different patterns of $\mathrm{Pb}$ isotope ratios from sediments, soils, and zinc smelting and this needs further investigation in order to identify atmospheric $\mathrm{Pb}$ sources.
\end{abstract}

Key words: Lead isotope, source tracking, sediment, heavy metal

\section{Introduction}

Lead is one of ubiquitous contaminant in environment due to its wide uses in the history of mankind. Recognized its adverse impacts, global actions have been launched to reduce lead uses in gasoline and to phase out lead-based paint and other lead-containing products, which causes reductions in atmospheric lead concentration. The important releases of lead might be grouped into three categories: natural sources such as volcanic activities and weathering rocks; current anthropogenic releases such as intentional uses in products and processes and unintentional release from fossil fuels and ores; historic anthropogenic release from sediment, soil, tailings and waste, etc.

Lead isotopes have been used to identify and distinguish between natural and anthropogenic sources of lead contamination in recent days. Lead isotope ratios are variable in natural materials and environment due to the radioactive decay of $\mathrm{U}$ - and Th-nuclides. The ratios did not changed during transport and deposition and retain the isotopic composition of its sources, which make lead isotopes good tracers for environmental source tracking (Choi MS., 2007)

From the previous study, the average lead concentration in sediment from Lake Andong was $72.5 \pm 10.8 \mathrm{mg} / \mathrm{kg}$ which is quite higher than NOAA's ERL (Effects Range-Low) criteria of $46.7 \mathrm{mg} / \mathrm{L}$. Thus, in this study, stable lead isotope compositions were measured in water and sediment from Lake Andong, particles in the air, soils, and stream water, mine tailings, sludge and wastewater from zinc smelting around lake Andong watershed to identify the lead contamination sources of sediment in Lake Andong.

\section{Materials and Methods}

The studied site, the watershed of Lake Andong was located in the Southeast Korea Lake Andong, an artificial freshwater lake is located on the upstream of the Nak-dong River. Within the watershed, there are more than 100 abandoned mines and one of the largest zinc smelter. The recent results showed that mercury concentrations in atmosphere, soils and plants appeared to decrease with a distance from the zinc smelter. This indicated the zinc smelter had a local impact of mercury emission.

For $\mathrm{Pb}$ isotope analysis, we collected water and sediment from Lake Andong, particles in the air, soils, and stream water, mine tailings, sludge and wastewater 


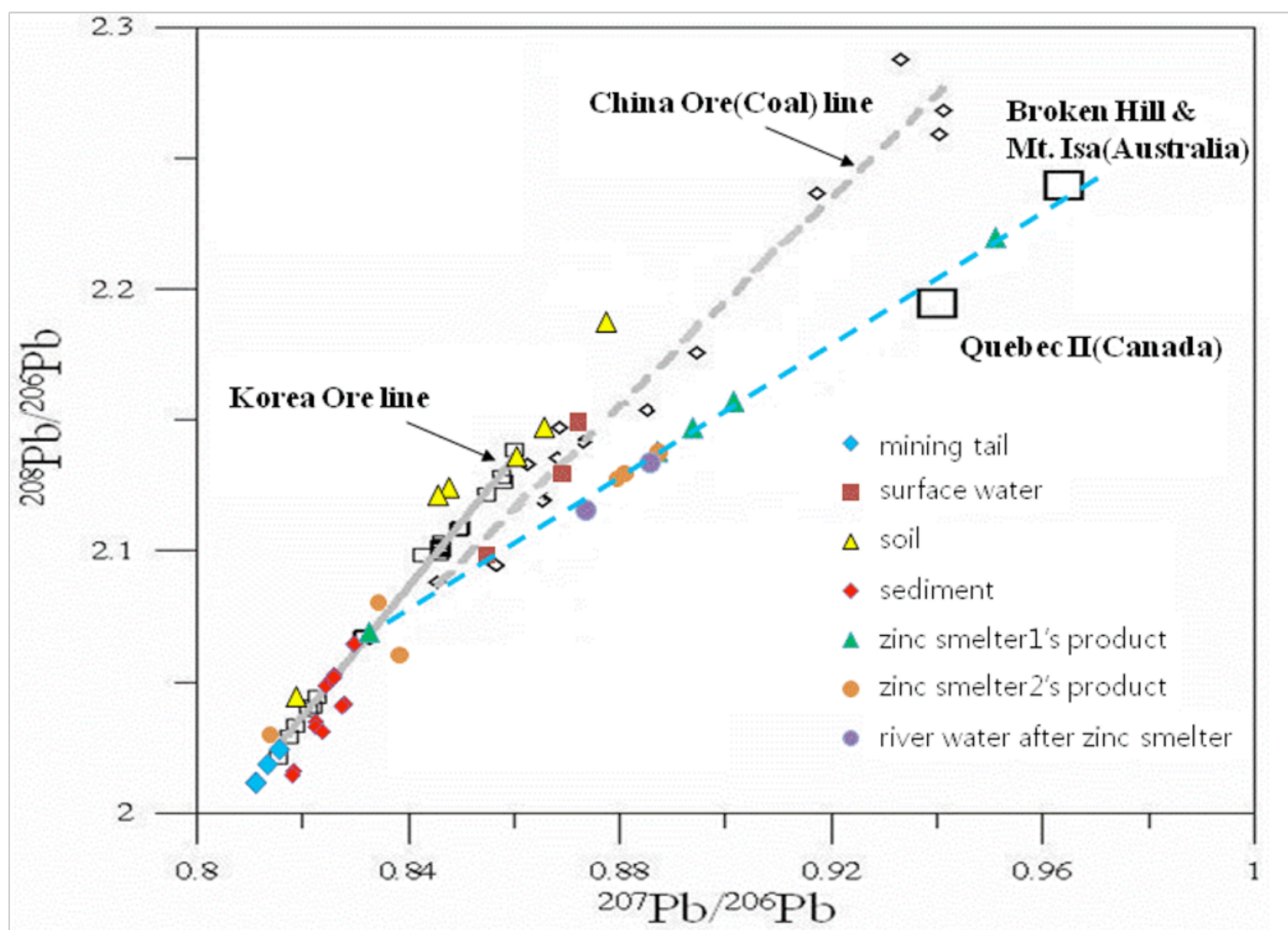

Fig. 1. Plot of three isotopes in environmental samples collected from Lake Andong watershed and in ore and sludge from zinc smelters.

from zinc smelting around lake Andong watershed during 2010 - 2011.

For metal analysis, the samples were digested using EPA method 3051 with $\mathrm{HNO}_{3} / \mathrm{HCl}$ and analyzed by ICP-OES (Optimer 5000DV, Perkin Elmer). Lead isotopes were measured using multi-collector ICP/MS (MC-ICP/MS; AXIOM MC, ThermoElemental Ltd.) in Korea Basic Science Institute. The detailed procedures were discribed elsewhere.

\section{Results and Discussion}

Lead isotope ratios in zinc ores used in the zinc smelter ranged from 0.816 to 0.956 (mean 0.832 ) and from 2.029 to 2.219 (2.059) for ${ }^{207} \mathrm{~Pb} /{ }^{206} \mathrm{~Pb}$ and ${ }^{208} \mathrm{~Pb} /{ }^{206} \mathrm{~Pb}$, respectively. The ores have a broad range of isotopic composition, which might be contributed from the geogenic differences of mining areas. Lead isotope ratios in sludge and wastewater from the zinc smelter ranged from 0.883 to 0.905 (mean 0.887 ) and from 2.127 to 2.156 (2.133) for ${ }^{207} \mathrm{~Pb} /{ }^{206} \mathrm{~Pb}$ and ${ }^{208} \mathrm{~Pb} /{ }^{206} \mathrm{~Pb}$, respectively. The isotopic composition of the residues from the smelter was in a narrow range compared to zinc ores. As shown in Fig.1, isotopic composition of the ores and residues from the smelter fall within the array attributed to Canadian and Australia's zinc ore. This result is consistent with records that most of zinc ores used in the smelter is imported from Canada, Peru and Australia (Alyssa E.S. et al., 2010).

The isotopic compositions of ${ }^{207} \mathrm{~Pb} /{ }^{206} \mathrm{~Pb}$ and ${ }^{208} \mathrm{~Pb} /{ }^{206} \mathrm{~Pb}$ are $0.827 \pm 0.004$ and $2.041 \pm 0.015$ for the sediments and $0.815 \pm 0.002$ and $2.016 \pm 0.006$ for the mining tails. Mining tails have similar isotopic composition with the sediments, but showed more radiogenic, lower isotope ratios. The isotope ratio of the sediments from Lake Andong showed more radiogenic compositions than River Han and River Guem reported from previous study.

Compared to the sediments, soils showed less radiogenic isotope ratios: $0.855 \pm 0.021$ and $2.126 \pm$ 0.047 for ${ }^{207} \mathrm{~Pb} /{ }^{206} \mathrm{~Pb}$ and ${ }^{208} \mathrm{~Pb} /{ }^{206} \mathrm{~Pb}$, respectively. The sediment samples plot on the mixing line trending towards two end-members of soils and mining tails and the mixing line tentatively attributed to Korean ore line. Generally, if a linear trend can be obtained from the isotope ratio and the inverse of concentration, the samples may be mixtures of two component end-members. Lead concentrations were $72.5 \pm 10.8$ 


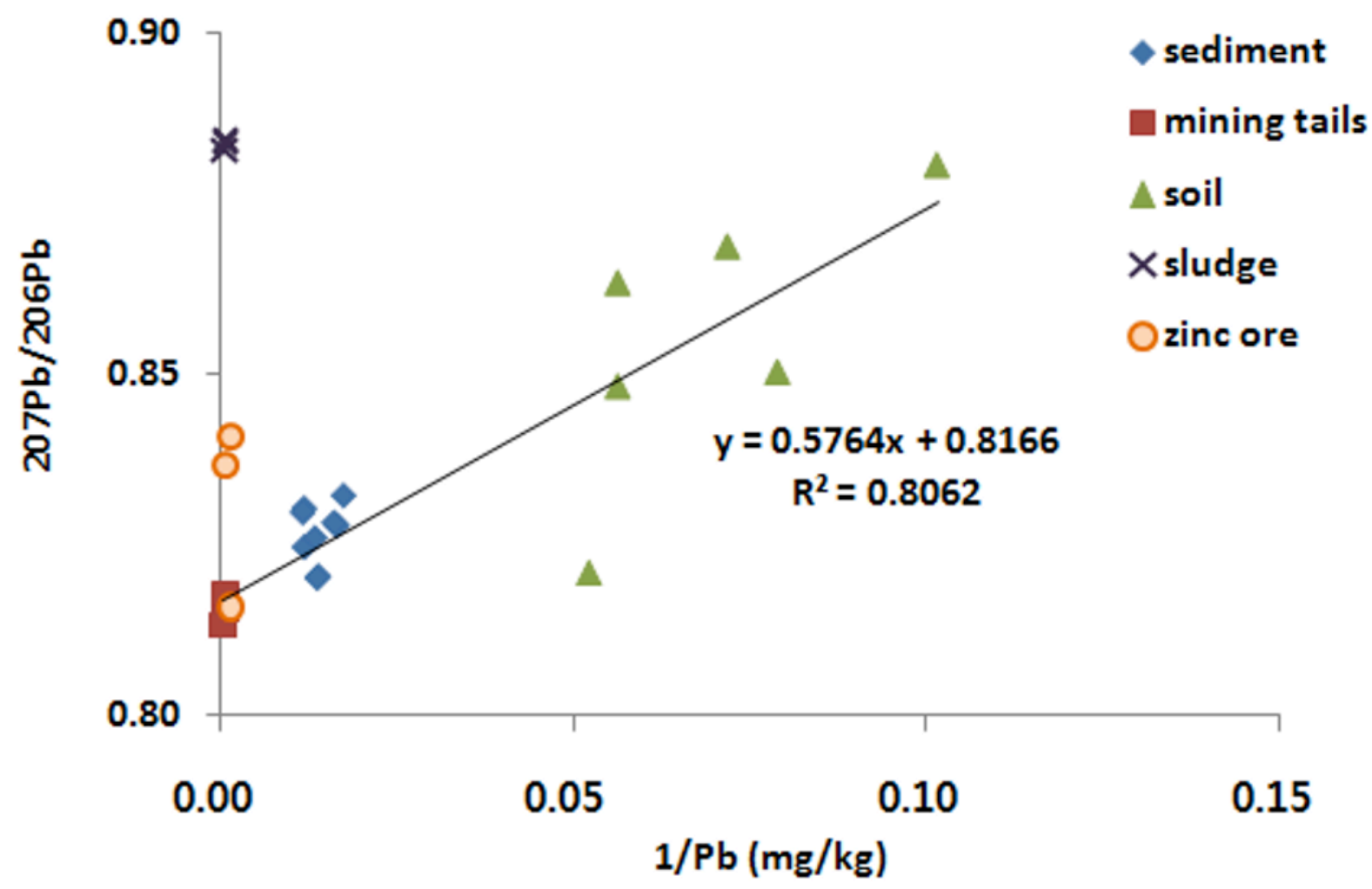

Fig. 2. Isotope ratio and the inverse of lead concentration of the environmental samples collected from Lake Andong watershed and in ore and sludge from zinc smelters

$\mathrm{mg} / \mathrm{kg}, 16.0 \pm 3.9 \mathrm{mg} / \mathrm{kg}$ and $1,639.6 \pm 406.4 \mathrm{mg} / \mathrm{kg}$ for sediment, soil and mining tails, respectively. Lead concentrations of zinc ore and sludge were also high, ranging $1,397.2 \pm 1,286.6 \mathrm{mg} / \mathrm{kg}$ and $1,566.8 \pm 180.2$ $\mathrm{mg} / \mathrm{kg}$. As shown in Fig. 2 lead isotope ratios in sediment, soil and mining tails exhibited a linear trend against the inverse of lead concentrations. Two components of soil and mining tails showed mixing relationships for sediments.

\section{Acknowledgements}

The authors thank the technical supports providing from
Korean Basic Science Institute.

\section{References}

Choi MS, Yi HI, Yang SY, Lee CB, Cha HJ. Identification of $\mathrm{Pb}$ sources in Yellow Sea sediments using stable $\mathrm{Pb}$ isotope ratios. Marine Chemistry 2007, 107: 255-274.

Alyssa E.S., Dominique W., Kristin J. Orians. Evaluation of zinc, cadmium and lead isotope fractionation during smelting and refining. Science of the total environment 2010, 408: 2357-2368. 